\title{
Socio-economic Effect of Modern Inclusive Discursive Practices in Disabled People's Social Rehabilitation
}

Irina Sovetovna Karabulatova ${ }^{1}$

Leonid losifovich Kim

\section{Gulmariam Hisamutdinovna Aznabaeva²}

Nadezhda Gennadievna Iraeva²

\section{Olga Aleksandrovna Konnova²}

${ }^{1}$ Institute of Social and Political Sciences of the Russian Academy of Sciences 2Ufa State University of Economics and Service, 450078, Ufa, Chernyshevsky St., 145

\section{Doi:10.5901/mjss.2015.v6n6s3p11}

\section{Abstract}

Fundamental changes which happen in the field of political, economic life in Russia have a great impact on the efficiency of the rehabilitation work with various socially vulnerable groups of the population. The basis for the development of a complex of rehabilitation measures are researches in a wide range of branches of knowledge: sociology, economy, psychology, pedagogics, medicine, science of law, criminology. Practical realization of the rehabilitation work will be possible only when a number of social and economic, organizational and administrative, pedagogical, social and psychological, legal and staffing issues will be decided. Persons with various health problems can emerge in any family and in any social conditions, in any ethnic group and anywhere in the world. Unfortunately, a disabled person in Russian submission is crippled, demanding care sufferer. That is why in the Russian and post-Soviet public consciousness disability is a synonym of poverty and hopelessness. However, recently in the post-Soviet space the social inclusion on the basis of ethno-cultural communities realizing new discursive practices directed on rehabilitation and adaptation of persons with limited health opportunities in everyday life of the society has experienced considerable changes. The world experience testifies that at the corresponding education and real helps persons, who have restrictions on health, can become valuable members of the society, regardless of the system of social protection that, finally, testifies for the high civil status of the society. Today, as the UNO says, in the world there are about 450 million people who have these or those mental and/or physical health disorders. In general they form 1/10 part of inhabitants of all over our planet. Moreover, as the World Health Organization (WHO) shows, a number of disabled children in the world is $13 \%$. Among them $3 \%$ of children are born with intelligence disorders, and $10 \%$ - with other mental or physical problems. In total in the world there are now about 200 million children with limited health opportunities. At the same time, various environmental issues find a tendency to the increased number of disabled children in the world, in the post-Soviet space in particular. So, in Russia for the last decade the frequency of children's disability has doubled: as the WHO calculations show about 900 thousand of children's population are disabled children (Blinkov, 2005, p. 8). Relevance of this problem is caused by the fact that various forms of new services - psychological consultations, centers of social services, social shelters, "telephone emergency services ", etc. actively take root into practice of the social work, but their development in many respects is at a loss for the lack of a system approach, scientific and practical base in the field of complex rehabilitation. Now, among many forms of the development of social services of the population, rehabilitation of disabled people in rehabilitation centers occupies an actual direction. The paper presents the unique experiment on social rehabilitation of persons with limited health opportunities which is realized within the social project of the Akmolinsk regional society of Germans (Republic of Kazakhstan). So, the rehabilitation work considered as the activity of integrated experts directed on restoration, or compensation of the broken or lost abilities of a person to performance of public, professional and household functions according to their interests, can be presented as the direction of social services in protection, preservation and development of health of the population, the decreased social tension in the society, improvement of the quality of life the diaspora. Because, as a rule, diaspora groups are age-related members of the society, the offered experience of the Kazakhstan society of the German culture can be interesting as a new discursive practice of socialization and adaptation of persons with limited health opportunities.

Keywords: social work, persons with limited opportunities, rehabilitation, ethno-cultural communities. 


\section{Introduction}

There are no doubts that the purpose of any rehabilitation is health, working capacity, personal and social status recovery, integration and reintegration of disabled people into usual living conditions of the society. Now the critical moment of the Russian history forms issues: "who is a viable person", "how to keep health of a nation in stress conditions". The knowledge of essential determinants and a strategy of rebirth of a viable person in stress circumstances of his existence, stops being only a theoretical task, and becomes a topical issue for everyday practice of rehabilitation of socially vulnerable groups of the population - disabled people.

The analysis of the history development of a problem concerning disability testifies that, having passed a way from ideas of physical destruction, isolation of "defective" members of the society to concepts of attraction them into the work, the mankind has approached to understanding of the need for reintegration of persons with physical defects, pathophysiological syndromes, psychosocial disorders. To draw the world community's attention to problems of disability and studying of potential opportunities of this special group of the population, on 3 December, according to the decision of the UNO, the International day of disabled people is spent. In 1993 the United Nations General Assembly has accepted Standard rules on equal opportunities creation for the people having disability. The World Health Organization has formulated the main approaches to understanding of "disability" as a standard for the world community:

- Any loss or violation of the psychological, physiological or anatomical structure or function;

- Limitation or absence (because of insufficiency) of the ability to carry out functions this way as it is normal for an average person;

- Difficulty following from insufficiency or disability which prevents a person fully or partially to carry out any role (including influence of age, sex and cultural accessory).

Thus, a "social" approach to determination of disability has to be the basis for providing services to disabled people and for the general policy development in the work with this group of the population.

By social rehabilitation is understood a package of measures directed on restoration of a person's ability to the activity in the social environment, these are the programs and actions directed on recovery of the personal and professional status of the person for fuller integration into the society. Social rehabilitation is the interdependent process, on one hand, directed on restoration of the ability of a person to the activity in the social environment, on the another - on the environment character change limiting realization of a person's needs.

Social rehabilitation is realized by means of inclusive discursive practices directed on: 1) social rehabilitation, 2) medico-social rehabilitation, 3) socio-legal rehabilitation, 4) psychology and pedagogical rehabilitation, 5) social and 6) labor rehabilitation. Rehabilitation is the complex, multilevel, landmark and dynamic system of interconnected actions directed on a person's recovery in his rights, status, health, capacity in the society (Albrecht, 2005).

Adaptation can be one of rehabilitation means. On the other hand, rehabilitation methods are used during adaptation. !!!!!! And all these things are directed on a common goal achievement - providing social help by restoration, preservation or improvement of the ability to social functioning and social improvement ensuring. And citizens' social health, families' prosperity is a necessary condition of the stable and progressive development of the country. Socialization of a disabled person is the process of mastering by a disabled person of socially significant norms, values, behavior stereotypes, their adjustment during mastering of various forms of social interaction. By socialization is also understood mastering by disabled people of knowledge, skills, stereotypes of behavior, valuable orientations, standards providing their full participation in standard forms of social interaction.

Training means the help to a disabled person in compensation of psychological changes (when a congenital or acquired defect takes the central place in formation of the personality), in formation of positive aims, on the development of other abilities of disabled people that will compensate disability.

Training is directed on mastering by a disabled person the standard schemes of behavior and interaction, on mastering by a disabled person of a surrounding situation and valuable existence in it. It includes adaptive consultation and the organization of the social participation of a disabled person, it must prepare him for adequate answers to the requirement of the environment and the active impact on it. The process of socialization has its own features depending on a type of disabling pathology, sex and age of a disabled person, features of his social status.

So, for example, disabled people with mental deficiency can reach a certain degree of independence by means of intensive mastering of behavioral skills, learning and use of stereotypic sets of the action by them which are necessary and standard life situations. Special training of such disabled people must provide a perception by them the surrounding society and reaction to it in the form of stereotypic for the culture submissions and actions.

For disabled people aged from 16 to 25 years the existence of the activity restriction can aggravate the difficulties of life support and communication which have people at this age that can cause a change of the personality, its social 
isolation and lead to asocial behavior. Socialization programs of disabled people must be directed towards the existing activity restrictions overcoming, on the search of ways of realization of own opportunities.

An economic and social situation of disabled people (education, qualification, family, economic situation, urban saturation of the district where a disabled person lives, etc.) plays an important role in his socialization. An unfavorable economic and social situation of a disabled person quite often leads to that that he does not get the qualified help; the level of their socialization - the adaptation to existing conditions (Miles, 2007). It is no coincidence that M. Miles notes a certain degree of social deafness peculiar to separate ethno-cultural communities, first of all, countries of Africa and Asia where the overpopulation takes place. In other words, the social policy concerning disabled people is a part of the domestic policy of the state having the certain legal basis presented in social programs, the practical activity and considering the society relations in interests and through needs of disabled people.

As the legislation claims, the policy for disabled people must be directed on providing them equal with other citizens opportunities in realization of economic, social, cultural, political and personal rights claimed by the Constitution of the country and their activity restrictions elimination for the purpose of recovery of the social status of disabled people, their achievement of material independence.

A social and psychological situation which is gradually developing in the post-Soviet space for the last 20 years has led to radical breaking of public consciousness and vital orientation of millions of people. Developing conditions of psycho-emotional pressure and mental disadaptation in essence are a natural "experimental model" of social stressful frustrations. That is why a problem of social rehabilitation is elimination or compensation of that "social deficiency" which is developing owing to the illness or otherwise - compensation of a difference between social sufficiency and social insufficiency which patient with permanent disorders of functions of the organism has.

Social services will mobilize all opportunities to help people to live at home, in usual and habitual human environment (Kobersy et al., 2015). And those who need additional support are provided with the visits of day hospitals which are within striking distance from home.

At the same time all this system is not able now to compensate and overcome difficulties which a disabled person is confronted by especially at the first stages of adaptation to new living conditions and life support. As a rule, for the majority of them disability is connected with the financial position deterioration, the loss of former social communications and status, this situation is aggravated by the feeling of isolation from the outside world, psychological depression and loneliness. Thus, not only disabled people, but also relatives, intimate people, members of their families experience psychological problems.

When a person experiences disability, there are real difficulties both of a subjective and objective character on adaptation to new vital conditions. A disabled person is limited to the education is in many respects complicated, to employment, cultural, sporting events access, the public transport is almost not adapted for the use by persons with disability, all this to a greater extent promotes the feeling of alienation. A disabled person as if go to the parallel world isolated from the rest of the society where he remains with his own problems face to face. A closed space and limitation of communication lead to nervous disorders bringing additional difficulties for relatives and persons serving disabled people. The social work is urged to overcome this state, to help a disabled person to adapt to the new environment of life, first of all, in rehabilitation.

The common basis and guiding principle for taking measures in the national and international plan in protection of rights of disabled people, is the Declaration on rights of disabled people accepted by the United Nations General Assembly of 09.12.1971.

The Law "On social services of elderly aged citizens and disabled people" divides the system of social services into two main sectors - state and non-state. A public sector is formed by federal and municipal bodies of social services (watch the list of federal laws specified in the list of references).

A non-state sector of social services unites institutions which activity is based on the forms of ownership which are not related to state or municipal, and also persons which are carrying out the private activity in the sphere of social services. Public associations including professional, charitable and religious organizations are engaged in non-state forms of social services.

\section{Materials and Methods}

The paper has used the following methods of research: 1) a method of the analysis of documents (international, federal, regional acts and programs, research and methodical literature on this problem were analyzed); 2) an interviewing method; analysis of data (qualitative methods (compression of information, submission); 3) the quantitative methods (statistical description, statistical conclusion). 
As the material the present research has used the data obtained during providing the specialized help focused on socially vulnerable groups of citizens, stations of social medical care of the Akmolinsk regional society of Germans "Widergeburt" in Kokshetau (Kazakhstan), societies of the Tatar culture of Tyumen. The organization of such inclusions in the social life of persons with disorders of the musculoskeletal system allows creating discursive practices in such a way that a person experiences stronger motivation to adaptation in new conditions and develops new skills in disability conditions.

The organization of such help at the Akmolinsk regional society of Germans "Widergeburt" of in Kokshetau is caused by that that this society includes elderly aged persons, as a rule, who owing to their age features have these or those pathologies of the musculoskeletal system, neurotic and mental disorders owing to long stress in concentration camps during the World War II. As pathologies of the musculoskeletal system we consider pathologies caused by injuries of the ankle joint because they refer to often found injuries of the musculoskeletal system, and their share, as literature shows, is from 6 to $21 \%$ of a total number of injuries of the musculoskeletal system and $40-60 \%$ - from a number of injuries of the lower extremity (Kopysova, Kaplun \& Gerasimov, 2000). As a rule, injuries of the tendinous-ligamentous apparatus of the ankle joint are the main reason for calling a traumatologist. A variety of approaches to diagnostics and treatment of these injuries testifies that this problem is still not solved and therefore remains actual. Because of it, this category of persons has later experienced more serious pathologies leading to restrictions of a way of life because of disability (Kim \& Dyachkova, 2013).

Social diagnostics play an important role in formation and development of technologies of the social work with disabled people. It is the methodical tool giving to a specialist necessary for the social work knowledge on the basis of which the social diagnosis of a problem of a disabled person is made, technologies of the social work allowing resolving existing difficulties in the activity of a physically disabled person are chosen.

A special category of "objects" of services by social workers is represented by a family in which there is a disabled person who need the outside help (Kobersy et al., 2015). Such a family is the microenvironment where lives a person who need the social support. He as if involves it in the orbit of the aggravated need for social protection. This special research has set that among 200 families with disabled members in 39,6\% of them there are disabled people (Dementeva, Shatalova \& Sobol, 1992).

\section{Results}

Long inactivity relaxes a person, reduces his power opportunities, and the work raises vitality, being a natural stimulator. Also long social isolation of a disabled person gives the undesirable psychological effect.

The labor therapy was of particular importance during the treatment of mental diseases which often are the reason of long isolation of a patient from the society. The labor therapy facilitates relationships between people, removing the state of intensity and concern. Employment and attention concentration on the performed work distract a patient from his painful feelings.

The society of the German culture of the Akmolinsk area (the chairman - Bergh Igor Vernerovich), having pronounced traditions of the patriarchal structure, attention to elderly people of the association, has organized such form of the inclusive work which allows persons with limited health opportunities to remain being included in life of a ethnocultural group. A sector of social protection plays an important role in the society of Germans. The social help is given to needy pensioners, Labour Army members, disabled people, lonely with a minimal pension, large families of Astana and the Akmolinsk Region (Akkol, Astrakhan, Arshalynsk, Ereymentaus, Tselinogradsk, Kurgaldzhins, Shortandinsk areas). It helps people of German nationality and a certain percentage of representatives of other ethnoses - to victims of political repressions, Labor Army members, disabled people, large families and lonely people. It provides free of charge hot lunches, dry rations, grocery sets, medical services. Thanks to cooperation with one of pharmaceutical firms, for very needy there are always expensive and effective preparations which are also provided free of charge to these categories of citizens. In the society there are more than 3 hundred beneficiaries who are on the books, and on the staff there are officially doctors of the main practice, narrow experts and also a social work coordinator. A number of appeals to the Akmolinsk regional society of Germans increases every year, mostly they are elderly, lonely patients demanding constant attention and care. This unique project is conducted by a therapist Valentina Ishaleeva. Differentiated diagnostics is conducted by a doctor Kim Leonid.

For rehabilitation the physical therapy and labor therapy also under supervision and direct participation of a specialist-doctor are used. For example, the labor therapy plays a noticeable role at diseases and injuries of the bone and articulate system preventing the development of permanent anchylosis (immovability of joints) which are frequency for elderly people. 
Often persons having these or those health restrictions have a quite low income therefore by forces of the society so-called "the grocery help" was organized for them. Volunteers of the German society do not just bring products, but also conduct conversations in a native language that allows brightening up sunset days of human "autumn". This range of the help is supervised by a doctor Svetlana Korneeva.

The gerontological aspect in social rehabilitation of persons with limited health opportunities is realized at "School of the third age" where they meet the lectures of doctors, are engaged in various circles on interests. This project solves to some extent the problem of loneliness, and also helps to realize a creative potential of elderly people and disabled people involving them in the public life. Besides, the German social fund provides free of charge addressees with glasses, hearing aids, wheelchairs, money for various operations. This innovation is focused on support of disabled people and persons with limited health opportunities by healthy members of an ethno-cultural group. It should be noted that the organization of such work within the ethno-cultural community is in a certain extent innovative and is realized not at the expense of resources of public organizations of disabled people, but at the expense of members of the unified ethno-cultural community and international structures. Such level of the organization of the help is not widespread though it has a high potential of adaptation.

This new type of inclusion was begun thanks to the Akmolinsk regional fund of rehabilitation assistance, the help to victims of Stalinism and Labor Army members (E.Ayrikh Fund) which is included into the structure of the society "Widergeburt" and operates on the Charter basis. The main task of the Fund is to protect social rights of rehabilitated citizens - victims of political repressions, former Labor Army members and members of their families. On April, 1990 in Akmola the first meeting of Labor Army members of the area, where the regional Fund was created, took place. Except the work on restoration of the historical truth and justice, preservation and perpetuating of memory of victims of terror, the Fund of Labor Army members is actively engaged in charity, for example, gives the social support to needy groups of the German population, organizes the visits for elderly aged, disabled people at home, distribution and delivery to needy parcels with humanitarian aid, medicine, clothes, etc. On June, 1990 on the regional society "Widergeburt" initiative the Tselinogradsk (Akmolinsk) city council of People's Deputies made the decision on establishment of privileges to Labor army members on the equal basis with veterans of the Great Patriotic War. A big group of Labor Army members was provided with the corresponding certificates, many of them were given the help in search of documents confirming their stay in the Labor Army. On February, 1995 in the area the 2nd regional conference of Labor Army members where the Fund of Labor Army members was transformed to E.Ayrikh regional Fund of rehabilitation of victims of political repression and Labor Army members took place and delegates to the 1st republican congress were elected. Now the regional office of this Fund is headed by Elvira Adamovna Ivanova. The fund carries out the great work on assistance to Labor Army members and rehabilitated people. In particular, this Fund has achieved that the Red Cross and the government of Germany send medicine which is given to free of charge needy people. So, for example, on this line in autumn in 19932 planes with medicines were sent to the area. A small part among them was transferred to the regional society "Widergeburt". In a year the society has received additional $1200 \mathrm{~kg}$, and on October, 1995 - more than $3000 \mathrm{~kg}$ of preparations and medicines. All of them are donated to Labor Army members, disabled people and victims of political repression. Health recovery to former Labor Army members and just elderly people is a very important section in the work of the Fund and the council of Germans, but not only one. The regional society "Widergeburt" gives to Labor Army members the feasible financial support, has achieved that nominal parcels from the charitable society of Germany are received. For example, only in Akmola now live 350 former Labor Army members. Virtually, none of them are forgotten. They are regular, in particular needy people, provided the help with money, are given free of charge medicine by prescription, representatives of the Fund visit elderly people at home, they are interested in their needs. The regional office of E.Ayrikh Fund also tries to provide Labor Army members with the moral support, together with the cultural center "Aynkhayt" organize the evenings of memoirs, meetings with youth, the work of a video salon where it is possible to watch movies in German. It is already become a good tradition to invite Labor Army members in the German cafe "Hanover", to arrange for them free lunches, cultural programs, to spend the evenings of rest and other actions.

The authors know two such organizations in the former Soviet Union: 1) the social medical assistance station of the Akmolinsk regional society of Germans "Widergeburt",Kokshetau (Republic of Kazakhstan) and 2) the society of the Tatar culture with its international charitable intellectual and creative beauty contest among girls with limited health opportunities on the basis of the Public Youth Rehabilitation Organization of Disabled people of Tyumen "Optimist" (the head - Rinat Hamzin). The society of the Tatar culture of Tyumen realizes over ten years the international project among girls and women with limited health opportunities. Paying attention to values of the ethnic and Islamic culture according to which, helping such categories of citizens the Muslim comes nearer one step closer to the Allah's throne.

The purpose of rehabilitation must be not only elimination of painful manifestations, but also the development by them the qualities helping to adapt more optimal to the environment. Familiarity with people, who have overcome a 
situation of serious pathologies, realized in social and professional life, helps only "beginners, who has experienced a disability situation. Such projects have a high psychotherapeutic activity potential which is well influencing not only persons with limited health opportunities, but also healthy members of our society, helping to realize an important role of spiritual human qualities.

When carrying out rehabilitation actions it is necessary to consider the psychosocial factors in some cases leading to emotional stress, the growth of psychological pathology and developing of so-called psychosomatic diseases, and often - to demonstration of deviant behavior. Biological, social and psychological factors mutually intertwine at various stages of adaptation of a disabled person to life.

Thus, when developing rehabilitation actions it is necessary to consider both medical diagnosis, and features of the personality in the social environment. By that, in particular, the need for attraction to the work with disabled people of social workers and psychologists in the health system is explained because the border between prevention, treatment and rehabilitation is very conditional and exists for convenience of the development of actions. Nevertheless, rehabilitation differs from the usual treatment by that it provides the development through joint efforts of a social worker, a medical psychologist and doctor, on one hand, and a disabled person and his environment (first of family) - on the other hand, qualities helping optimal adaptation of a disabled person to the social environment. The treatment in this situation is the process more influencing the organism, on the present, and rehabilitation is more addressed to the personality, and it (rehabilitation) is directed to the future.

The work with ethno-trauma consequences which is carried out by the society of the German culture is aimed at improvement of the quality of those categories of citizens who have received various permanent physical and mental health disorders, with the use of of the medico-social service created by the society, the members of which are professional doctors of the main medical directions, diagnosticians, equipped offices with the European diagnostic equipment. It should be noted that these categories of citizens receive the free of charge help at the expense of the society which, in turn, receives various forms of the support from Germany. As a part of the German help can be not only diagnostics, treatment by doctors, but also allocation of medicines, means of rehabilitation (canes, wheelchairs) which the society receives from Germany on the grant basis.

In one stage for involvement of vulnerable categories in the active life of the society in general the German society holds competitions of socially significant projects which are financed by the association. So, $60-70 \%$ of financing of the winner project is carried out at the expense of financial means of Germany allocated by the government of Germany within the Program for the support of the German diaspora abroad. In general the competitive fund is 15000 euros. Among the directions of projects the priority ones are the following: 1) management in the network of the centers of meetings and youth work; 2) gender technologies; 3) information work and PR; 4) career guidance; 5) work with children; 6) work with volunteers and volunteer organizations; 7) social technologies; 8) youth work; 9) fundraising; 10) cultural and leisure-time technologies; 11) ecology. The organizers plan to attract a wide range of participants, i.e. these projects can be realized as international, republican and interregional ones where orientation goes on citizens of Kazakhstan, Uzbekistan, Kyrgyzstan (Zeyfert, 2007).

Health of countries of the former Soviet Union is in a critical condition. The urgent need for activization and consolidation of efforts of all ministries, departments, and also non-governmental public organizations in prevention, rehabilitation and adaptation of socially vulnerable groups of the population was brewing.

A variety of directions and kinds of the activity imposes the increased requirements to the volume of knowledge, skills which experts working in the centers of rehabilitation must possess. Until in a small extent training of such experts is organized, the search of innovative forms and methods taking into account specifics of concrete establishments is in the process.

\section{Discussion}

The results of basic researches testify to the crisis state of health by representatives of all age groups, especially by children. In Russia, as well as all over the world, a tendency to the growth of children with limited opportunities is observed. Since the end of the XX century the frequency of children's disability in our country has doubled and according to different data is from 6 to $9 \%$. At preservation of this tendency the forecast of the population future in our country is extremely pessimistic. Therefore, the problem of health preservation of the population, in particular health of children, becomes priority for the state (Dementeva \& Ustinova, 1995, p.6 \& Hernandez \& Isaacs, 1998).

Now the process of rehabilitation is an object of specialists' research of many branches of scientific knowledge. It is studied by psychologists, philosophers, sociologists, teachers, social psychologists etc. They open various aspects of this process, investigate mechanisms, stages, factors of social rehabilitation. (Social and labor rehabilitation of disabled 
people 2003, p. 3)

Mastering by disabled children of the social experience, inclusion in the existing system of the public relations demands from the society certain additional measures, means and efforts (they can be special programs, special centers for rehabilitation, special educational institutions, etc.). In this connection the society of the German culture uses programs allowing these children to remain within the ethno-culture, helping to be socialized. But the development of these measures must be based on knowledge of regularities, tasks, essence of the process of social rehabilitation (Declaration on rights of disabled people of the United Nations General Assembly: 16; N 135-FZ; N 442-FZ; N 122-FZ; N 181-FZ; N 832).

The idea, in fact, is not new, it is based on universal values of the help to the neighbor, Christian, Muslim and Buddhist morals (Miles, 2013; Rooshey et al, 2008; Yucel, 2006; Thomas, 2001; Gloria Zhang Liu, 2001 \& Ong, 1993).

The rehabilitation of socially vulnerable groups of the population which is carried out by the society of the German culture in the Akmolinsk area becomes an effective factor of mitigation of social, medical, psychological problems of disabled people and other categories of persons which are in a risk zone. At the present stage of economics development the providing complex social and medical care to the least socially protected groups of the population in the context of the habitual ethno-social world remains actual that raises an extent of adaptation and rehabilitation.

\section{Conclusion}

So, rehabilitation of socially vulnerable groups of the population becomes an effective factor of mitigation of social, medical, psychological problems of disabled people. Actual at the present stage of economics development is the providing complex social help to the least socially protected groups of the population.

A variety of directions and kinds of the activity imposes the increased requirements to the volume of knowledge, skills which experts working in the centers of rehabilitation must possess. Until in a small extent training of such experts is organized, the search of innovative forms and methods taking into account specifics of concrete establishments is in the process. The stage of casual tests and mistakes is inevitable in the course of formation of the new rehabilitation service.

The positive relation of the state and the society to the need for extension of the active and adapted to the modern social and economic living conditions of disabled people is the instrument of the strong social policy concerning these groups of the population.

\section{References}

Albrecht, G.L. (2005) Encyclopaedia of Disability. Thousand Oaks (CA): Sage Publications, Inc.

Belova, A.N. \& Shhepotova, O.N. (1998) «Rukovodstvo po reabilitatsii bolnyh s dvigatelnymi narusheniyami», - «Antidor», M.

Blinkov, Yu.A. (2005) Mediko-sotsialnaya ekspertiza lits s ogranichennymi vozmozhnostyami. Moskva.

Dementeva, N.F., Shatalova, E.Yu. \& Sobol, A.Ya. (1992) Organizatsionno-metodicheskie aspekty deyatelnosti sotsialnogo rabotnika. V kn.: Sotsialnaya rabota v uchrezhdeniyah zdravoohraneniya. M.: Departament problem semji, zhenshhin i detei MSZ RF; Centr obshhechelovecheskih tsennostei.

Dementeva, N.F. \& Ustinova, E.V. (1995) Rol i mesto sotsialnyh rabotnikov v obsluzhivanii invalidov i pozhilyh lyudei. M.

Zeifert, E. (2014) Novyi «lot» - mezhdunarodnyi seminar. Electronic resource. http://www.ru.mdz-moskau.eu/novyj-lot-mezhdunarodnyjseminar. Accessed date 20.08.2015.

Kim, L.I. \& Dyachkova, G.V. (2013) Kompleksnaya diagnostika povrezhdeny golenostopnogo sustava. V.: Geny ortopedii, №4, pp. 2024.

Kopysova, V.A., Kaplun, V.A. \& Gerasimov, O.N. (2000) Hirurgicheskoe lechenie tyazhelyh povrezhdeny oblasti golenostopnogo sustava. V: Novye tehnologii v meditsine : th. sc.-pract. conf. Kurgan. P. 1. pp. 141-142.

Kobersy, I., Karyagina, A., Karyagina, O., \& Shkurkin, D. (2015). Law as a Social Regulator of Advertisement and Advertising Activity in the Modern Russian Information Space. Mediterranean Journal Of Social Sciences, 6(3 S4), 9. Retrieved from http://www.mcser.org/journal/index.php/mjss/article/view/6705

Kuchinsky, S.S. (1996) Tsentry nemetskoi kultury v Rossii i za rubezhom. Iz opyta raboty Akmolinskogo oblastnogo obshhestva «Wiedergeburt», centra kultury «Einheit» i nemetskogo gumanitarno-obrazovatelnogo kompleksa (Kazahstan). Metodicheskoe posobie v pomoshh rukovoditelyam obshhestv i centrov nemetskoi kultury. Moskva: Gotika.

Miles, M. (2015) Disability and Deafness, in the context of Religion, Spirituality, Belief and Morality, in Middle Eastern, South Asian and East Asian Histories and Cultures. Electronic resource. http://www.independentliving.org/docs7/miles200707.html (date of base 15.08.2015).

Miles, M. (2013) Buddhism and responses to disability, mental disorders and deafness in Asia. West Midlands, UK.

Sotsialno-bytovaya i trudovaya reabilitatsiya invalidov (2003). M.: Editorial Publishing Centre of the Consortium «Sotsialnoe zdorove Rossii», TEIS.

Declaration on rights of disabled people of the United Nations General Assembly 
Federal Law of the Russian Federation from 28 December 2013. №442-FZ. "On key bases of social services of citizens of the Russian Federation». Electronic resource. http://www.rg.ru/2013/12/30/socialka-dok.html

Federal Law "On social services of elderly aged citizens and disabled people" from 2 Auguat 1995. №122-FZ. (ed. by. Federal laws from 10.01.2003 №15-FZ, ot 22.08.2004 №122-FZ). Electronic resource. http://www.psychepravo.ru/law/fz-rf/o-socialnomobsluzhivanii-grazhdan-fz-122.htm. accessed date to the base 19.08.2015.

Federal law of November 24, 1995 №181-FZ "On the social protection of disabled people in the Russian Federation" (with changes and additions) GARANT system: http://base.garant.ru/10164504/\#ixzz3jizknyC4

Federal law of August 11, 1995 №135-FZ "On charity and charitable organizations" (with changes and additions). GARANT system: http://base.garant.ru/104232/\#ixzz3jizSTbtS

Kobersy, I., Novikov, V., Shkurkin, D., \& Borisova, A. (2015). Investigation of the scope of intellectual services in the aspect of virtualizationand information economy of modern Russia. Mediterranean Journal Of Social Sciences, 6(5 S3).

Resolution of the Government of the Russian Federation of December 29, 2005 №832 "On the federal target program "Social Support of Disabled People for 2006 - 2010". GARANT system: http://base.garant.ru/189069/\#ixzz3jizDcEAV

Rooshey,Hasnain, Laura, Cohon \& Shaikh, Hasan Shanawani (2008) Disability and the Muslim Perspective: An Introduction for Rehabilitation and Health Care Providers. University at Buffalo; The State University of New York NY.

Yucel, I.S. (2006) Issues of health and disability in Islam. Presentation at Brigham and Women's Hospital, Boston, Massachusetts.

Thomas, M. (2001) Women with disabilities in South Asia. Women in Action. 13(5), 1-5.

Gloria, Zhang Liu (2001) Chinese Culture and Disability: Information For U.S. Service Providers. Center for International Rehabilitation Research Information and Exchange University at Buffalo The State University of New York.

Ong, W. (1993) Asian American Cultural Dimensions in Rehabilitation Counseling. San Diego, San Diego State University.

Hernandez, M. \& Isaacs, M. (1998) Promoting Cultural Competence in Children's Mental Health Services. Baltimore, MD: Paul H. Brookes Publishing Co. 